\title{
PENERAPAN MODEL MULTIDIMENSIONAL SCALING DALAM PEMETAAN BRAND POSITIONING INTERNET SERVICE PROVIDER
}

\author{
Robertus Tang Herman \\ Jurusan Manajemen, Fakultas Ekonomi dan Bisnis, Universitas Bina Nusantara, \\ Jln. K.H. Syahdan No. 9, Palmerah, Jakarta Barat 11480 \\ robertth@binus.edu
}

\begin{abstract}
In this high-tech era, there have been tremendous advances in tech-based products and services. Internet is one of them that have widened the world's eyes to a new borderless marketplace. High competition among internet service providers has pushed companies to create competitive advantage and brilliant marketing strategies. They undertake positioning mapping to describe product or service's positioning amongst many competitors. The right positioning strategy becomes a powerful weapon to win in the battle. This research is designed to create positioning mapping based on perceptual mapping. The researcher uses Multidimensional Scaling and image mapping to achieve this research goal. Sampling is using non-probability sampling in Jakarta. Based on non-attribute approach, the research findings show that there is similarity between two different brands. Thus, both brands are competing against one another. On the other hand, CBN and Netzap provider reflect some differences to others. And some brands require some improvements in terms of network reliability.
\end{abstract}

Keywords: multidimensional scaling, positioning, internet service provider

\begin{abstract}
ABSTRAK
Di era teknologi tinggi ini, telah banyak kemajuan dalam produk teknologi dan layanan berbasis. Internet adalah salah satu dari kemajuan yang telah melebarkan mata dunia terhadap sebuah pasar baru yang tanpa batas. Persaingan yang tinggi antara penyedia layanan internet telah mendorong perusahaan untuk menciptakan keunggulan kompetitif dan strategi pemasaran yang brilian. Mereka melakukan pemetaan positioning untuk mendeskripsikan posisi produk atau jasa antara banyak kompetitor. Strategi posisi yang tepat menjadi senjata ampuh untuk menang dalam kompetisi. Penelitian ini dirancang untuk membuat pemetaan posisi berdasarkan pemetaan persepsi. Peneliti menggunakan Skala Multidimensional dan pemetaan image untuk mencapai tujuan penelitian. Pengambilan sampel menggunakan sampling non-probability di Jakarta. Berdasarkan pendekatan non-atribut, temuan penelitian menunjukkan bahwa ada kesamaan antara dua merek yang berbeda. Dengan demikian, kedua merek bersaing satu sama lain. Di sisi lain, CBN dan penyedia Netzap mencerminkan beberapa perbedaan satu sama lain. Dan beberapa merek memerlukan beberapa perbaikan dari sisi kehandalan jaringan.
\end{abstract}

Kata kunci: skala multidimensional scaling, positioning, penyedia layanan internet 


\section{PENDAHULUAN}

Teknologi informasi melalui internet telah membuka mata dunia akan sebuah dunia baru, interaksi baru, market place baru, dan sebuah jaringan bisnis dunia yang tanpa batas. Disadari betul bahwa perkembangan teknologi internet, telah mengubah pola interaksi masyarakat, yaitu interaksi bisnis, ekonomi, sosial, dan budaya. Hadirnya internet telah menunjang efektifitas dan efisiensi operasional perusahaan dan masyarakat. Secara umum, dapat dikatakan bahwa internet relatif baru dikenal oleh masyarakat Indonesia dan frekuensi pemakainya pun belum terlalu banyak. Namun, perkembangan internet di Indonesia telah menunjukkan perkembangan yang signifikan. Menurut data APJII (Asosiasi Penyelenggara Jasa Internet Indonesia), akhir tahun 2008 jumlah pengguna internet di Indonesia sebanyak 40 juta orang dan jumlah pelanggan sebesar 6 juta orang. Hal ini menunjukkan peningkatan yang signifikan dari tahun-tahun sebelumnya. Persaingan yang sangat tinggi mendorong setiap perusahaan memiliki keunggulan bersaing dan strategi pemasaran yang tepat.

Selain marketing mix, perusahaan juga harus menyusun strategi segementing, targetting, positioning (STP) untuk dapat memenangkan persaingan. Pada akhirnya, penempatan produk sesuai dengan keinginan konsumen adalah tujuan utama seorang pemasar. Kondisi ini mendorong konsumen untuk bersikap lebih cermat dan selektif dalam menentukan produk atau jasa yang akan dipilih. Strategi STP, khususnya strategi Positioning yang tepat akan menstimulasi konsumen untuk memilih produk atau jasa yang akan ditawarkan berdasarkan keunggulan dan keunikan produk atau jasa tersebut untuk memenuhi kebutuhan konsumen.

Tujuan penelitian ini adalah untuk menghasikan sebuah Perceptual Map yang menggambarkan letak masing-masing produk dengan teknik Multidimensional Scaling (MDS). Perceptual Mapping akan menghasilkan product positioning menurut persepsi para konsumen berdasarkan atribut determinannya. Atribut merupakan faktor-faktor yang dipertimbangkan konsumen dalam menentukan persepsi terhadap suatu barang atau jasa dan pada akhirnya memutuskan pembelian atau penggunaan suatu produk jasa/tidak. Berdasarkan hal tersebut, penelitian melakukan penelitian ini dengan judul "Analisis Pemetaan Posisi Merek Internet Service Provider di Wilayah Jakarta dengan Metode Multi Dimensional Scaling (MDS)”. Indentifikasi masalah pada penelitian ini adalah untuk menjawab permasalahan-permasalahan, yaitu "Bagaimana posisi setiap produk broadband ISP secara relatif terhadap pesaingnya dalam pasar yang dipersepsikan oleh para responden?”, dan "Bagaimana persepsi atribut broadband ISP yang melekat pada setiap merek ISP menurut persepsi responden?”.

Positioning adalah suatu cara produk didefinisikan oleh konsumen berdasarkan beberapa atribut penting-tempat yang diduduki produk dalam benak konsumen, dibandingkan dengan produkproduk pesaing. Positioning suatu produk menuntut perusahaan untuk menanamkan keunikan manfaat dan diferensiasi merek ke benak pelanggan. Posisi produk adalah seperangkat rumit atas dari persepsi, kesan, dan perasaan konsumen terhadap produk tertentu dibandingkan dengan produk-produk pesaing (Kotler dan Armstrong, 2008:311. Prosedur untuk melakukan penempatan posisi yang tepat menurut Hiam dan Schewe yang dikutip oleh Hasan (2008:202), yaitu menentukan produk-pasar yang relevan, pendataan kebutuhan pelanggan, mengidentifikasi pesaing, menentukan standar evaluasi, membuat perceptual map, mengidentifikasi kesenjangan posisi, merencanakan dan melaksanakan strategi positioning.

Persepsi adalah suatu proses, di mana sensasi yang diterima oleh seseorang dipilah dan dipilih, kemudian diatur dan akhirnya diinterpretasikan. Sensasi datang dan diterima oleh manusia melalui panca indera, yaitu mata, telinga, hidung, mulut dan kulit, yang disebut juga sistem sensorik. Input sensorik atau sensasi yang diterima oleh sistem sensorik manusia disebut juga stimulus (Solomon dalam Prasetijo, 2005:67). Menurut Schiffman \& Kanuk (2007:136), individu bertindak dan bereaksi berdasarkan persepsi mereka, tidak berdasarkan realitas objektif. Jadi, bagi pemasar, persepsi konsumen jauh lebih penting daripada pengetahuan mereka mengenai realitas yang objektif. 
Internet Service Provider adalah perusahaan atau badan yang menyelenggarakan jasa sambungan internet dan jasa lainnya yang berhubungan. Klasifikasi Internet Service Provider (ISP) dapat dibedakan berdasarkan kecepatan dan teknologi yang digunakan, yaitu (1) Koneksi Dial-up. Koneksi internet ini menggunakan saluran telepon dengan kecepatan antara 40-50 Kbps; (2) Koneksi Broadband, di mana akses ini lebih cepat dibandingkan dengan koneksi dial-up dan tidak mengganggu pemakaian saluran telepon. Kecepatan antara 64 Kbps hingga 2 Mbps; (3) Koneksi Mobile Broadband. Koneksi ini merupakan akses layanan internet dengan menggunakan saluran telepon selular. Kecepatan yang dimiliki beragam hingga 7,2 Mbps.

Multidimensional Scaling (MDS) adalah salah satu teknik multivariate dalam golongan interdependence technique, MDS adalah salah satu prosedur yang digunakan untuk memetakan persepsi dan preferensi para responden secara visual dalam peta geometri. Peta geometri tersebut disebut spatial map atau perceptual map, merupakan penjabaran berbagai dimensi yang berhubungan. Secara umum, MDS dapat membantu untuk menentukan dimensi yang paling sering digunakan oleh responden dalam menilai suatu objek, berapa jumlah dimensi yang digunakan dalam penilaian tersebut, hubungan relatif dari masing-masing dimensi, dan hubungan objek yang diamati secara perseptual.

\section{METODE PENELITIAN}

\section{Desain Penelitian}

Penelitian ini merupakan jenis penelitian deskriptif dan eksploratif. Kombinasi pendekatan eksploratif dan deksriptif dimaksudkan untuk saling menunjang, di mana pendekatan eksploratori dipakai untuk melakukan riset deskriptif. Penelitian eksploratif adalah penelitian yang bertujuan menghimpun informasi awal yang akan membantu upaya menetapkan masalah dan merumuskan hipotesis. Dalam penelitian ini, pendekatan eksploratori dilakukan untuk memilih beberapa ISP yang akan menjadi objek penelitian serta atribut-atribut yang melekat pada ISP tersebut. Sedangkan penelitian deskriptif bertujuan untuk mengetahui nilai variabel mandiri, baik satu variabel atau lebih independen tanpa membuat perbandingan atau menghubungkan dengan variabel lain. Dalam penelitian in, penelitian deskriptif digunakan untuk menjawab permasalahan-permasalahan utama yang ada dalam penelitian ini. Unit analisis yang digunakan adalah individu (konsumen layanan internet service provider). Time horizon yang digunakan yaitu cross sectional di mana data yang dikumpulkan hanya satu kali, dalam kurun waktu tertentu.

\section{Operasional Variabel Penelitian}

Penelitian ini menggunakan interdependence techniques, di mana kedudukan setiap variabel sama, tidak ada variabel bebas dan variabel terikat. Yang diperiksa adalah interrelasi antarvariabel. Dari interrelasi itulah diambil kesimpulan-kesimpulan sesuai teknik yang dipakai. Variabel atribut yang digunakan adalah service (layanan), features (fitur-fitur), speed (kecepatan), coverage area (Jangkauan area), network reliability (Keandalan Jaringan), price (Harga). Data diperoleh dari persepsi konsumen terhadap merek-merek ISP dengan mengisi kuesioner yang telah disediakan dengan menggunakan semantic differential scale.

\section{Jenis dan Sumber Data Penelitian}

Penelitian ini menggunakan jenis data kualitatif yang dinyatakan dalam bentuk kata, kalimat atau gambar. Data kualitatif yang digunakan adalah data tentang positioning merek-merek ISP di Indonesia. Sedangkan data kuantitatif digunakan untuk mengetahui peta posisi non atribut dan peta 
atribut berdasarkan persepsi konsumen. Sumber data yang dikumpulkan merupakan data primer yang berasal dari sumber asli dan dikumpulkan secara khusus untuk menjawab permasalahan penelitian, yaitu kuesioner dan data sekunder yang diperoleh dari sekumpulan sumber lain, baik dari dalam maupun luar perusahaan yaitu berupa data profil perusahaan, data dari referensi jurnal, internet, dan buku.

\section{Teknik Pengumpulan Data}

Untuk mendapatkan data yang akan diolah, maka teknik pengumpulan data yang dilakukan penulis dalam penelitian ini adalah (1) Penelitian lapangan/riset lapangan (field research), yaitu wawancara, studi pendahuluan untuk menemukan permasalahan penelitian, dan kuesioner, menggunakan format pertanyaan yang menggunakan skala; (2) Studi kepustakaan/riset kepustakaan (library research), yaitu studi yang dilakukan dengan cara mempelajari buku- buku wajib (textbooks), buku-buku pelengkap atau referensi, majalah, jurnal, laporan resmi dari perusahaan dan catatan kuliah yang relevan dengan permasalahan yang diteliti. Studi kepustakaan ini dimaksudkan untuk memperoleh data sekunder dan landasan teori sebagai bahan untuk studi perbandingan.

\section{Teknik Pengambilan Sampel}

Untuk pengambilan sampel, penulis menggunakan teknik non probability sampling dengan teknik purposive sampling. Teknik pengambilan sampel dalam penelitian ini dimaksudkan untuk menduga/ mewakili nilai suatu populasi. Populasi dalam penelitian ini adalah pengguna rumahan Broadband Internet service provider (ISP) di Jakarta. Berdasarkan data dari APJII (2001) jumlah pengguna internet rumahan lebih dari 700.000 orang. Sedangkan lebih dari 30\% pengguna berada di daerah Jakarta sehingga populasi pengguna ISP di wilayah Jakarta \pm 250.000 orang. Berdasarkan tabel penentuan jumlah sampel dari populasi tertentu yang dikembangkan dari Isaac dan Michael, untuk tingkat kesalahan 5\% jumlah sampel yang ditentukan sebesar 348 responden.

\section{Metode Analisis}

Uji Cochran digunakan digunakan pada data dengan skala nominal atau untuk informasi dalam bentuk terpisah dua (dikotomi) misalnya informasi “ya" atau "tidak”. Penggunaan uji ini adalah untuk mengetahui keberadaan hubungan antara beberapa variabel.

Hipotesis pengujian:

Ho= Kemungkinan jawaban "ya” adalah sama untuk semua variabel (asosiasi)

$\mathrm{Ha}=$ Kemungkinan jawaban "Ya” adalah berbeda untuk semua variabel (asosiasi)

Analisis Multidimensional Scaling (MDS) berhubungan dengan pembuatan grafik (map) untuk menggambarkan posisi sebuah objek dengan objek yang lain, berdasarkan kemiripan (similarity) objek-objek tersebut. Syarat pembuatan jumlah pasangan objek penelitian dalam data kemiripan (similarity), yaitu nomor pasangan yang diperbandingkan untuk memperoleh tingkat kemiripan atau keserupaan adalah n(n-1)/2, di mana $n$ adalah total jumlah objek. Pendekatan yang digunakan dalam analisis MDS adalah similaritas (persepsi), yaitu (1) Similaritas non-atribut (persepsi langsung). Pendekatan ini menghasilkan peta persepsi non-atribut; (2) Similaritas atribut (persepsi tidak langsung). Pendekatan ini menghasilkan peta persepsi atribut.

Tabel 1 Metode Analisis Berdasarkan Tujuan Penelitian

\begin{tabular}{cc}
\hline Tujuan & Alat Analisis \\
\hline T-1 & Multidimensional Scaling (MDS) \\
T-2 & Multidimensional Scaling (MDS) \\
\hline
\end{tabular}




\section{Rancangan Implikasi Penelitian}

Rancangan implikasi hasil penelitian ini adalah sebuah positioning merek-merek Broadband ISP berupa peta persepsi yang dihasilkan berdasarkan persepsi responden, memberikan gambaran keadaan persaingan antar merek Broadband ISP di wilayah Jakarta menurut persepsi responden, dapat menganalisis posisi setiap produk Broadband ISP di wilayah Jakarta dari sisi atribut dan non-atribut pada peta persepsi, yang juga membantu perusahaan mengetahui atribut yang paling dominan dalam pemilihan sebuah merek Broadband ISP. Diharapkan hasil penelitian ini dapat memberikan hasil yang memuaskan kepada Telkom Speedy pada PT Telekomunikasi Indonesia dan perusahaan penyedia jasa layanan internet lainnya dan juga para konsumen atau pengguna ISP. Dengan begitu, PT Telekomunikasi Indonesia dapat menempatkan produk dan menentukan strategi yang tepat dalam pasar persaingan antar merek Broadband ISP.

\section{HASIL DAN PEMBAHASAN}

\section{Uji Validitas dan Reliabilitas}

Uji Validitas untuk setiap instumen dilakukan dengan terlebih dahulu dicari harga korelasi antara bagian-bagian dari alat ukur secara keseluruhan dengan cara mengkorelasikan setiap butir alat ukur dengan skor total yang merupakan jumlah tiap skor butir. Untuk menghitung validitas alat ukur digunakan rumus Pearson Product Moment. Uji validitas menggunakan tingkat kepercayaan 95\%, di mana $\mathrm{df}=\mathrm{n}$-2. Nilai $\mathrm{n}$ menggunakan data sebanyak 348 jawaban kuesioner. Jadi nilai $\mathrm{df}=346$, Selanjutnya dengan menggunakan rumus $\mathrm{r}_{\text {tabel, }}$, maka didapatkan nilai $\mathrm{r}_{\text {tabel }}=0,165$.

Dasar pengambilan keputusan pada uji validitas ini adalah sebagai berikut: Jika $\mathrm{r}_{\text {hitung }}$ positif, serta $\mathrm{r}_{\text {hitung }}>0,165$, maka butir pertanyaan tersebut valid;

Jika $\mathrm{r}_{\text {hitung }}$ tidak positif, serta $\mathrm{r}_{\text {hitung }}<0,165$, maka butir pertanyaan tersebut tidak valid.

Nilai $r_{\text {hasil }}$ didapat dari hasil perhitungan korelasi Pearson Product Moment antara skor tiap butir pertanyaan dengan skor total.

Dasar pengambilan keputusan pada uji reliabilitas adalah sebagai berikut:

Jika Cronbach Alpha $>\mathrm{r}_{\text {tabel}}$, maka dapat dikatakan reliabel;

Jika Cronbach Alpha $<\mathrm{r}_{\text {tabel, }}$, maka dapat dikatakan tidak reliabel.

Jika Cronbach Alpha (R Alpha) lebih besar dari 0.60, maka dinyatakan Reliabel (Santoso, 2005:251).

Tabel 2 Uji Validitas Kuesioner Awal

\begin{tabular}{cccccc}
\hline No.pertanyaan & $\mathbf{1}$ & $\mathbf{2}$ & $\mathbf{3}$ & $\mathbf{4}$ & $\mathbf{5}$ \\
\hline R hitung & 0,308 & 0,335 & 0,349 & 0,342 & 0,460 \\
R tabel & 0,165 & 0,165 & 0,165 & 0,165 & 0,165 \\
kesimpulan & Valid & Valid & Valid & Valid & Valid \\
\hline \multicolumn{1}{c}{} & & & & \\
\hline No.pertanyaan & $\mathbf{6}$ & $\mathbf{7}$ & $\mathbf{8}$ & $\mathbf{9}$ & $\mathbf{1 0}$ \\
\hline R hitung & 0,313 & 0,372 & 0,453 & 0,294 & 0,531 \\
R tabel & 0,165 & 0,165 & 0,165 & 0,165 & 0,165 \\
kesimpulan & Valid & Valid & Valid & Valid & Valid \\
\hline
\end{tabular}

Sumber: Hasil pengolahan validitas menggunakan SPSS 16.0 
Tabel 3 Uji Validitas Kepentingan Atribut

\begin{tabular}{ccccccc}
\hline No.pertanyaan & $\mathbf{1}$ & $\mathbf{2}$ & $\mathbf{3}$ & $\mathbf{4}$ & $\mathbf{5}$ & $\mathbf{6}$ \\
\hline R hitung & 0,490 & 0,538 & 0,323 & 0,602 & 0,412 & 0,419 \\
R tabel & 0,088 & 0,088 & 0,088 & 0,088 & 0,088 & 0,088 \\
kesimpulan & Valid & Valid & Valid & Valid & Valid & Valid \\
\hline
\end{tabular}

Tabel 4 Hasil Uji Realibilitas Kuesioner Awal Reliability Statistics

\begin{tabular}{ccc} 
& \multicolumn{3}{c}{$\begin{array}{c}\text { Cronbach's } \\
\text { Alpha Based on } \\
\text { Cronbach's } \\
\text { Alpha }\end{array}$} & $\begin{array}{cc} \\
\text { Standardized } \\
\text { Items }\end{array}$ & N of Items \\
\hline .701 & .722 & 10 \\
\hline
\end{tabular}

Tabel 5 Hasil Uji Realibilitas Kepentingan Atribut Reliability Statistics

\begin{tabular}{|c|c|c|}
\hline $\begin{array}{c}\text { Cronbach's } \\
\text { Alpha }\end{array}$ & $\begin{array}{c}\text { Cronbach's } \\
\text { Alpha Based on } \\
\text { Standardized } \\
\text { Items }\end{array}$ & $N$ of Items \\
\hline .716 & .734 & 6 \\
\hline
\end{tabular}

\section{Analisis Penentuan Atribut}

Hal pertama agar penelitian ini lebih efektif dilakukan pre test, dengan menggunakan cochran's Q sebagai alat analisis (non-parametric test-k related sample), diperoleh data sebagai berikut:

Tabel 6 Uji Cochran Q test

\begin{tabular}{cc}
\hline \multicolumn{2}{c}{ Test Statistics } \\
\hline$N$ & 100 \\
Cochran's $Q$ & $8.293^{\mathrm{a}}$ \\
$d f$ & 5 \\
Asymp. Sig. & .141 \\
\hline
\end{tabular}

Setelah melakukan uji Cochran berkali-kali terhadap 10 atribut-atribut yang melekat pada Internet service provider (ISP), Maka hasil akhir diperoleh 6 atribut yang melekat pada Internet service provider (ISP) dengan nilai Cochran's Q sebesar 8.293, di mana Q hitung $<$ Q tabel, atau 8.293 $<11.070$ yang berarti Ho diterima untuk menyatakan ke-6 atribut memiliki kemungkinan jawaban YA yang sama untuk semua atribut. Dengan kata lain, ke-6 atribut dapat dianggap sah sebagai atribut sebuah Internet service provider (ISP). Enam atribut Internet Service Provider (ISP) tersebut adalah Service, Network reliability, Speed, Coverage area, Price, dan Features. 


\section{Analisis Posisi Broadband ISP Secara Relatif terhadap Pesaingnya}

Pendekatan non atribut memberikan kebebasan kepada responden untuk menyatakan persepsinya terhadap tingkat kemiripan antar stimulus (merek Broadband ISP) tanpa terikat oleh atribut yang telah ditentukan. Dalam penelitian ini, akan digunakan pembuatan dengan menggunakan dua dimensi dengan mempertimbangkan beberapa faktor diantaranya adalah kemudahan penggunaan dua dimensi lebih tinggi dibandingkan denga tiga dimensi atau lebih. Selain itu, interpretasi data dan konfigurasinya lebih mudah dilakukan dengan 2 dimensi (Tabel 7).

Tabel 7 Configuration Derived in Two Dimensions

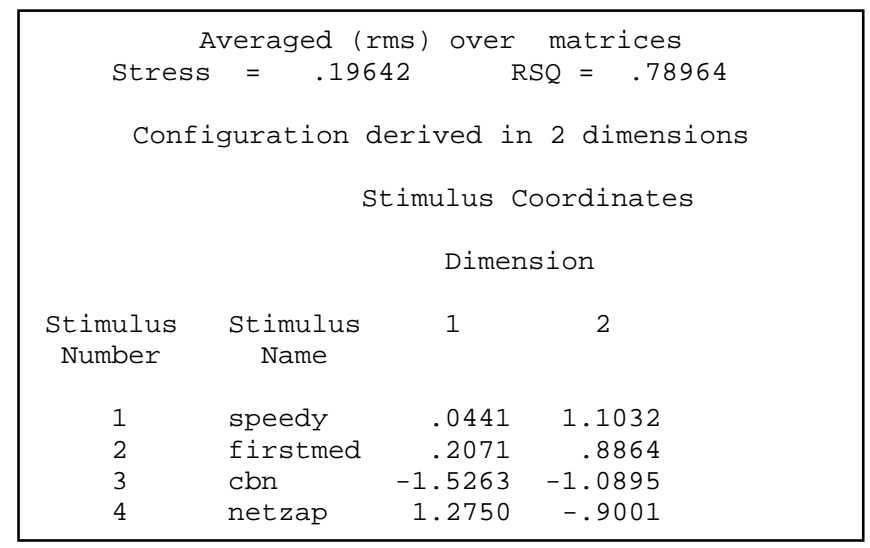

Berdasarkan hasil pengolahan data persepsi konsumen dengan menggunakan program MDS, diperoleh peta posisi Broadband ISP dengan nilai stress sebesar 0,19642 dan index of fit $\left(\mathrm{R}^{2}\right)$ sebesar 78,964\%. Berdasarkan pedoman nilai stress menurut Johnson \& Wichhern (1982) termasuk dalam kategori "fair" (cukup) dan nilai index of fit sebesar 78,964\% dikatakan telah memenuhi kelayakan (index of fit dikategorikan layak jika $>60 \%$ ) (Malholtra,1996). Stimulus coordinates menunjukkan koordinat peta posisi dari masing-masing Broadband ISP yang dinyatakan dalam 2 dimensi. Nilai tersebut menunjukkan kemiripan dan jarak nilai kedekatan antar merek Broadband ISP. Dari stimulus coordinates ini, kemudian dinyatakan dalam konfigurasi peta posisi Broadband ISP yang dapat dilihat pada Gambar 1.

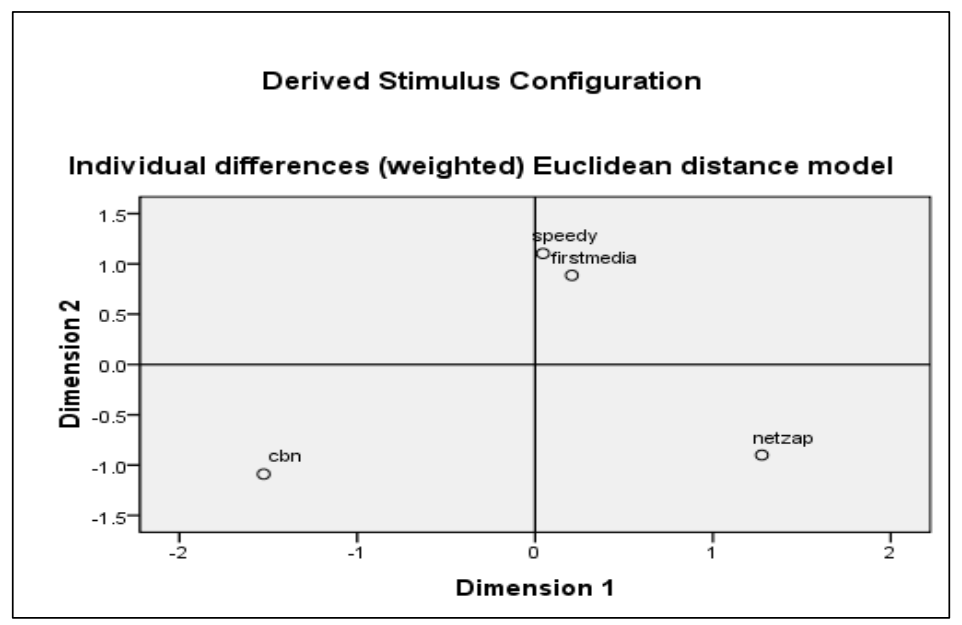

Gambar 1 Peta Persepsi Non-atribut Broadband ISP 
Pada Gambar 1, terlihat bahwa merek Speedy ternyata mempunyai keimiripan dengan Firstmedia karena letaknya berdekatan dan berada dalam kuadran yang sama. Sedangkan merek CBN dan Netzap teletak jauh antara satu dengan yang lainnya, dengan kata lain kedua merek tersebut berbeda dengan pasangan merek yang lain. Hasil analisis dari sudut dimensi 1 dan 2 dapat diuraikan sebagai berikut. Pertama, Dimensi 1, yaitu (1) Speedy, Firstmedia, Netzap memiliki satu posisi golongan merek yang mempunyai kemiripan relatif sama; dan (2) Sedangkan CBN memiliki posisi yang berbeda dengan pasangan kelompok lainnya. Kedua, Dimensi 2, yaitu (1) Speedy dan Firstmedia memiliki satu posisi golongan merek yang relatif sama; dan (2) Sedangkan CBN dan Netzap memiliki posisi berbeda dengan pasangan kelompok lainnya. Ketiga, baik dilihat dari dimensi 1 maupun dimensi 2, responden menganggap bahwa Speedy dan Firstmedia memiliki kemiripan satu sama lain (dalam artian Speedy mirip dengan Firstmedia dan sebaliknya Firstmedia mirip dengan Speedy) sehingga merek Firstmedia merupakan pesaing terdekat Speedy begitu juga sebaliknya. Sedangkan CBN dan Netzap berbeda dengan yang lainnya.

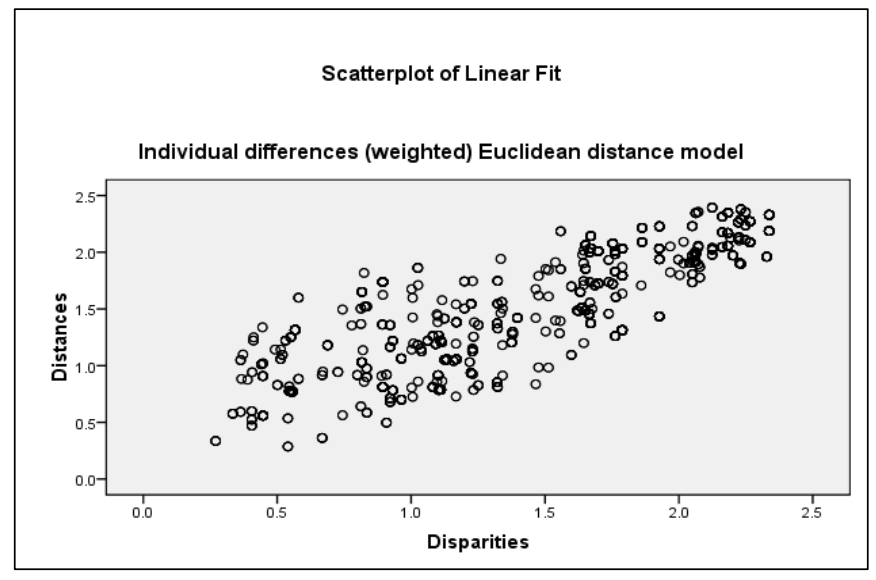

Gambar 2 Scatterplot of Linear Fit

Pendekatan non atribut juga mengukur tingkat homogenitas persepsi responden, dengan membandingkan antara bobot persepsi individu dengan bobot persepsi agregat. Tingkat homogenitas persepsi ini ditunjukkan oleh grafik scatterplot of linear fit terlihat bahwa titik-titik koordinat membentuk kelompok koordinat yang konfigurasinya membentuk garis dari kiri bawah ke kanan atas. Hal ini menunjukkan bahwa responden memiliki sikap homogen terhadap kemiripan antar merek Broadband ISP.

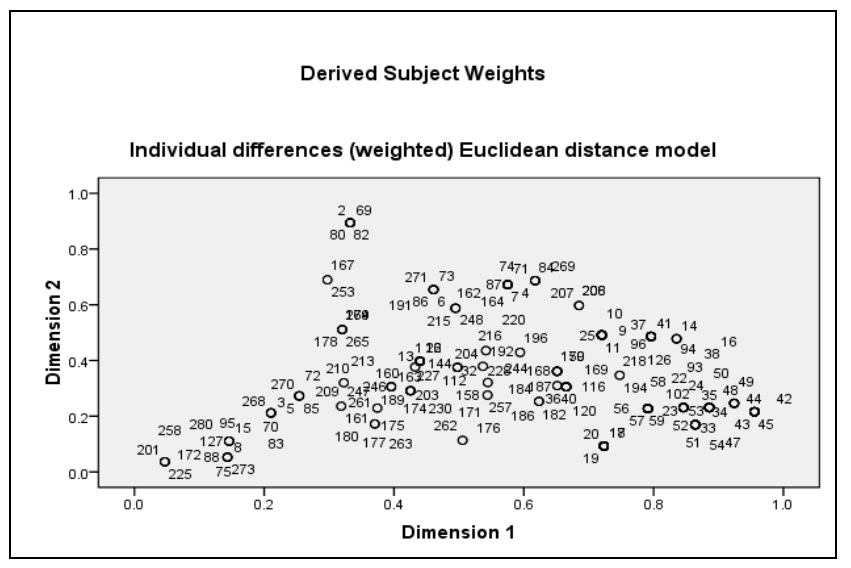

Gambar 3 Derived Subject Weights 
Grafik Derived Subject Weights menjelaskan tentang keselarasan responden dalam memberikan penilaian kemiripan. Pada Gambar 3, terlihat posisi ke 348 responden dapat dibentuk sebuah kelompok di bagian kanan bawah grafik menunjukkan bahwa penilain responden terhadap keempat merek Broadband ISP menunjukkan suatu konsistensi. Berdasarkan nilai output yang dihasilkan SPSS, diperoleh nilai rata-rata bobot dimensi dari semua responden (subject weight). Bobot dimensi ini menunjukkan nilai yang diberikan responden dalam melakukan pembedaan terhadap stimulus untuk setiap dimensi. Nilai rata-rata bobot dimensi tersebut adalah sebagai berikut (1) Dimensi 1 memiliki nilai bobot sebesar 0,4815; dan (2) Dimensi 2 memiliki nilai bobot sebesar 0,1398. Nilai rata-rata di atas menunjukkan bahwa nilai dimensi 1 lebih besar dari nilai rata-rata dimensi 2, yang berarti responden lebih mementingkan (cenderung menggunakan) dimensi 1 dibandingkan dimensi 2 dalam menentukan kemiripan antar merek (stimulus).

\section{Analisis Persepsi Atribut yang Melekat pada Setiap Merek Broadband ISP}

Dalam pendekatan non atribut yang menghasilkan output peta persepsi non atribut hanya dapat memberikan informasi bahwa di antara merek-merek Broadband ISP tersebut memiliki kemiripan yang tergambar dalam posisi masing-masing merek dalam peta. Namun, pada peta persepsi non atribut belum mampu memberikan dalam hal apa saja (atribut) merek-merek tersebut mengalami kemiripan (berdekatan). Oleh karena itu, dibutuhkan penggunaan pendekatan atribut yang dapat membantu memperoleh informasi tersebut. Dalam penelitian ini, analisis atribut dilakukan dengan menggunakan prosedur image mapping. Data penilaian atribut merek-merek dijadikan dasar pembuatan image mapping.

Di dalam penelitian ini, digunakan bantuan nilai rata-rata (mean), yaitu dengan menjumlahkan pada setiap merek berdasarkan atribut yang telah dinilai oleh responden dengan skala 1 sampai 5 titik, di mana angka 1 menunjukkan sikap yang negatif dan angka 5 menunjukkan sikap yang positif.

Tabel 8 Nilai Rata-rata (Mean) Penilaian Atribut oleh responden

\begin{tabular}{ccccccc}
\hline & Service & Speed & Price & $\begin{array}{c}\text { Network } \\
\text { Reliability }\end{array}$ & $\begin{array}{c}\text { Coverage } \\
\text { Area }\end{array}$ & Features \\
\hline Speedy & 3.50 & 3.42 & 3.02 & 3.54 & 3.79 & 4.01 \\
Firstmedia & 2.96 & 3.32 & 3.41 & 3.58 & 2.91 & 3.98 \\
CBN & 3.40 & 2.70 & 2.79 & 2.72 & 3.68 & 3.20 \\
Netzap & 2.83 & 3.29 & 3.32 & 2.89 & 1.99 & 2.90 \\
\hline
\end{tabular}

Berdasarkan Tabel 8, dapat diperoleh sebuah pemetaan citra (image mapping) yang terdiri dari 6 atribut, masing-masing atribut memiliki nilai rata-rata (mean) untuk tiap merek yang diwakili oleh garis dengan warna-warna tertentu. Berikut ini adalah keterangan garis yang dipakai (1) Warna merah, mewakili merek Broadband ISP Speedy, (2) Warna biru, mewakili merek Broadband ISP Firstmedia, (3) Warna hijau, mewakili merek Broadband ISP CBN, dan (4) Warna ungu, mewakili merek Broadband ISP Netzap. Dalam langkah selanjutnya, angka-angka kinerja atribut akan divisualisasikan ke dalam peta citra (image mapping) dengan menggunakan warna-warna yang telah dipilih untuk merepresentasikan setiap merek. Hasil image mapping dapat dilihat pada gambar berikut (Gambar 4). 


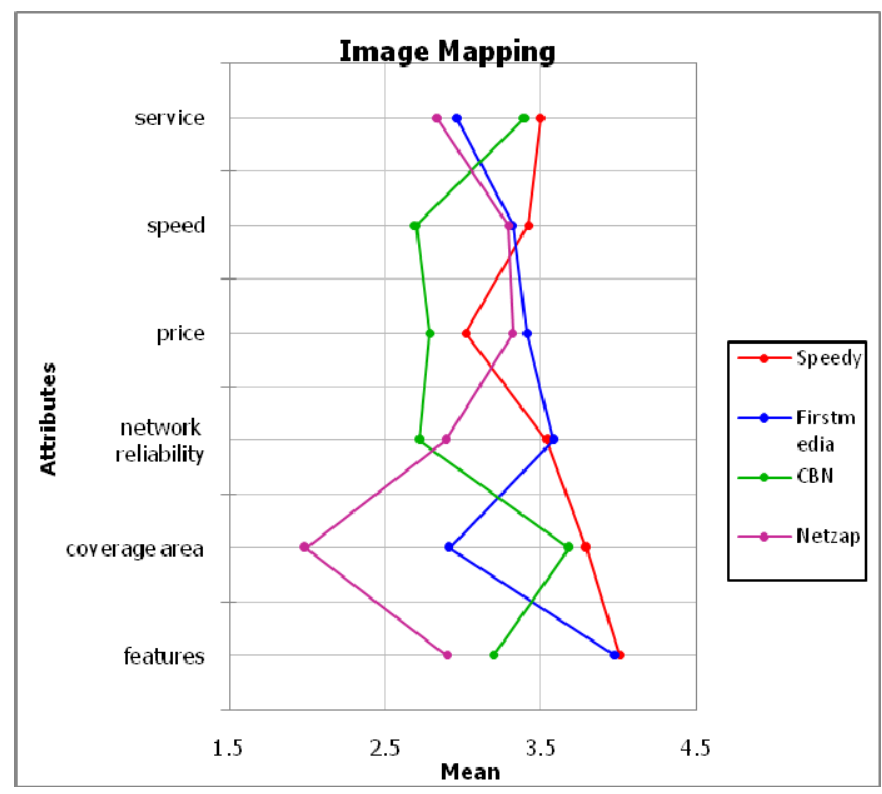

Gambar 4 Image Mapping

Berdasarkan peta persepsi non atribut (Gambar 1) dan peta atribut yang dihasilkan melalui image mapping (Gambar 4), dapat dilihat posisi antar merek Broadband ISP secara lebih jelas. Hasil interpretasi kedua peta tersebut sebagai berikut. Pertama, dimensi 1 pada persepsi non atribut menunjukkan bahwa merek Broadband ISP Speedy, Firstmedia dan Netzap bersaing satu sama lainnya (posisi berdekatan di mana Speedy, Firstmedia dan Netzap berada pada kuadran yang sama) sedangkan merek CBN berada posisi yang berbeda dengan merek lainnya. Namun, pada peta persepsi non atribut tidak dapat menjelaskan dalam atribut-atribut apa merek-merek tersebut bersaing berdasarkan persepsi konsumen. Oleh karena itu, peta atribut yang dihasilkan image mapping dapat membantu dengan interpretasi " Pada atribut speed (kecepatan) dan price (harga) terlihat garis berwarna merah, biru dan ungu berada pada posisi yang berdekatan. Hal ini menunjukkan Speedy, Fisrtmedia dan Netzap menempati posisi yang berdekatan, yang berarti pada atribut speed (kecepatan) dan price (harga) ketiga merek Broadband ISP tersebut saling bersaing.”

Kedua, dimensi 2 pada peta persepsi non atribut menunjukkan bahwa merek Broadband ISP Speedy dan Firstmedia berada pada posisi kuadran yang sama sehingga kedua merek tersebut saling bersaing. Sedangkan merek Broadband ISP CBN dan Netzap berada pada posisi yang berbeda dengan kelompok merek pertama. Namun, dengan menggunakan image mapping dapat dilihat lebih jelas dalam atribut-atribut apa saja mereka bersaing. Hasil interpretasi image mapping adalah "Pada atribut network reliability (keandalan jaringan), terlihat garis berwarna merah dan biru saling berdekatan. Hal ini menunjukkan merek speedy dan firstmedia menempati posisi yang berdekatan, yang berarti pada atribut network reliability (keandalan jaringan) kedua merek tersebut bersaing. Begitu pula dengan atribut network features (fitur-fitur), di mana posisi speedy dan firstmedia juga saling berdekatan yang mengindikasikan kedua merek tersebut saling bersaing."

Ketiga, selain pasangan merek tersebut, image mapping juga menunjukkan posisi merekmerek lain yang juga bersaing cukup dekat, namun tidak tercermin dalam peta persepsi non atribut. Pada atribut service (layanan) dan coverage area (jangkauan area), terlihat garis berwarna merah dan hijau berada pada posisi yang berdekatan. Hal ini menunjukkan merek Broadband ISP Speedy dan CBN bersaing secara dekat pada atribut service (layanan) dan coverage area (jangkauan area). 
Berdasarkan hasil image mapping yang telah diuraikan diatas, dapat diketahui bahwa peta persepsi non atribut mengindikasikan merek-merek yang saling bersaing dan image mapping menjelaskan dalam atribut apa saja merek-merek tersebut bersaing berdasarkan persepsi konsumennya. Dengan demikian, merek Broadband ISP yang memiliki posisi berdekatan pada atribut tertentu dapat dilakukan penentuan positioning nya. Posisi Broadband ISP relatif terhadap persaingan berdasarkan persepsi konsumen yang diinterpretasikan pada hasil image mapping menunjukkan bahwa (1) Merek Speedy, Firtsmedia dan Netzap bersaing satu sama lainnya pada atribut speed (kecepatan) dan price (harga); (2) Merek Speedy dan Firstmedia bersaing satu sama lainnya pada atribut network reliability (keandalan jaringan) dan features (fitur-fitur); dan (3) pada atribut service (layanan) dan coverage area (jangkauan area), merek Speedy dan CBN saling bersaing satu dengan lainnya.

\section{Positioning Broadband ISP}

Positioning yang akan dijelaskan dalam penelitian ini mengenai masing-masing merek Broadband ISP, dapat dilihat dari hasil image mapping (Gambar 4). Speedy, berdasarkan hasil data responden mendapatkan nilai yang positif hampir pada seluruh atribut namun kurang pada atribut price (harga). Firstmedia, berdasarkan hasil data responden mendapatkan nilai yang positif pada atribut Speed (kecepatan), Price (harga), Network reliability (keandalan jaringan), Features (fiturfitur). Sedangkan CBN, berdasarkan hasil data responden mendapatkan nilai yang positif pada atribut Service (layanan), Coverage area (jangkauan area), Features (fitur-fitur). Dan pada merek broadband Netzap, berdasarkan hasil data responden mendapatkan nilai yang positif pada atribut Speed (kecepatan) dan Price (harga). Berdasarkan image mapping yang telah terbentuk barulah dapat diperbandingkan positioning yang dijalankan perusahaan melalui persepsi konsumen terhadap merekmerek Broadband ISP.

\section{Tinjauan Positioning Broadband ISP}

Tinjauan yang dilakukan terhadap positioning setiap merek Broadband ISP yang menjadi objek penelitian ini adalah selain untuk mengevaluasi upaya positioning yang telah dilakukan sampai saat ini juga untuk menghasilkan kesimpulan apakah perlu dilakukan suatu repositioning atas produk tersebut. Melalui tinjauan positioning yang dilakukan, positioning yang dilakukan oleh Broadband ISP Speedy, Firstmedia dan Netzap sudah tepat sehingga perusahaan dapat terus menjalankan positioning yang ada saat ini. Sedangkan melalui tinjauan positioning yang dilakukan, positioning yang dilakukan CBN kurang tepat. Hal ini ditunjukkan berdasarkan positioning yang dimiliki CBN yaitu kualitas layanan sesuai dengan persepsi responden. Namun, pada atribut keandalan jaringan yang tinggi tidak sesuai dengan persepsi responden. Oleh karena itu perusahaan akan lebih baik melakukan perbaikan terhadap positioning yang ada saat ini.

\section{Implikasi Hasil Penelitian}

Berdasarkan penelitian yang dilakukan, penulis ingin mengetahui bagiamana posisi masingmasing merek broadband ISP berdasarkan peta persepsi (perceptual map) yang dihasilkan oleh responden di wilayah Jakarta. Dengan meninjau bagaimana positioning yang dilakukan perusahaan dengan persepsi responden, maka dapat diketahui apakah positioning yang dilakukan perusahaan ini sudah tepat. Setelah analisis dilakukan, maka didapatkan peta posisi non atribut yaitu merek broadband ISP Speedy memiliki kemiripan satu sama lain dengan broadband ISP Firstmedia. Sehingga kedua merek tersebut merupakan pesaing terdekat. Sedangkan merek ISP CBN dan Netzap berbeda dengan lainnya. Sedangkan pada peta posisi atribut, diketahui bahwa atribut yang paling dominan dalam pemilihan sebuah merek broadband ISP adalah atribut price (harga) dan speed (kecepatan). 


\section{SIMPULAN}

Berdasarkan hasil pengolahan data dan analisis data yang telah dilakukan, maka dapat disimpulkan sebagai berikut. Berdasarkan analisis peta persepsi non atribut, terdapat 2 dimensi. Pertama, Dimensi 1, yaitu (1) Speedy, Firstmedia, Netzap memiliki satu posisi golongan merek yang mempunyai kemiripan relatif sama; (2) Sedangkan CBN memiliki posisi yang berbeda dengan pasangan kelompok lainnya. Kedua, Dimensi 2, yaitu (1) Speedy dan Firstmedia memiliki satu posisi golongan merek yang relatif sama; (2) Sedangkan CBN dan Netzap memiliki posisi berbeda dengan pasangan kelompok lainnya. Ketiga, baik dilihat dari dimensi 1 maupun dimensi 2, responden menganggap bahwa Speedy dan Firstmedia memiliki kemiripan satu sama lain (dalam artian Speedy mirip dengan Firstmedia dan sebaliknya Firstmedia mirip dengan Speedy), sehingga merek Firstmedia merupakan pesaing terdekat Speedy begitu juga sebaliknya. Sedangkan CBN dan Netzap berbeda dengan yang lainnya. Pendekatan atribut dilakukan dengan image mapping, di mana dapat memberikan dan menunjukkan dalam hal apa saja merek-merek tersebut mengalami kemiripan (bersaing), hasilnya sebagai berikut (1) Merek Speedy, Firtsmedia dan Netzap bersaing satu sama lainnya pada atribut speed (kecepatan) dan price (harga); (2) Merek Speedy dan Firstmedia bersaing satu sama lainnya pada atribut network reliability (keandalan jaringan) dan features (fitur-fitur); (3) Pada atribut service (layanan) dan coverage area (jangkauan area), merek Speedy dan CBN saling bersaing satu dengan lainnya. Dengan melakukan tinjauan perbandingan positioning antara positioning yang disampaikan oleh perusahaan dengan positioning hasil penelitian, didapatkan hasil sebagai berikut (1) Pada merek Broadband ISP Speedy, terdapat kesesuaian antara positioning yang dilakukan perusahaan dengan positioning hasil penelitian, yaitu pada atribut speed (kecepatan) dan service (kualitas layanan); (2) Pada merek Broadband ISP Firstmedia, terdapat kesesuaian antara positioning yang dilakukan perusahaan dengan positioning hasil penelitian, yaitu pada atribut speed (kecepatan) dan price (harga); (3) Pada merek Broadband ISP CBN, terdapat kesesuaian antara positioning yang dilakukan perusahaan dengan positioning hasil penelitian, yaitu pada atribut service (kualitas layanan). Tetapi, juga terdapat gap antara positioning yang disampaikan perusahaan dengan positioning pada hasil penelitian ini, yaitu pada atribut network reliability (positioning yang disampaikan perusahaan) dengan atribut coverage area (positioning CBN pada penelitian ini); (4) Pada merek Broadband ISP Netzap, terdapat kesesuaian antara positioning yang dilakukan perusahaan dengan positioning hasil penelitian, yaitu pada atribut speed (kecepatan) dan price (harga).

Berdasarkan hasil analisis positioning dan persepsi konsumen yang dilakukan dalam penelitian ini, maka saran yang dapat diberikan oleh peneliti adalah sebagai berikut. Pertama, perusahaan Speedy merupakan market leader dalam industri penyedia jasa layanan internet di Indonesia. Berdasarkan hasil penelitian, Firstmedia mempunyai posisi yang sangat baik dan merupakan pesaing terdekat Speedy. Oleh karena itu, Speedy harus memperhatikan dan terus memantau pesaing terdekatnya untuk mengantisipasi perpindahan pelanggan. Kedua, pelanggan jasa layanan internet (ISP) di indonesia mengutamakan atribut price (harga) dan speed (kecepatan) dalam menentukan persepsinya. Speedy sangat unggul dalam atribut kecepatan dibandingkan merek lainnya sehingga harus terus mempertahankan strategi saat ini. Namun, pada atribut harga, Firstmedia berada di atas Speedy. Oleh karena itu, Speedy harus berusaha memperbaiki kualitas harga yang ditawarkan agar dapat unggul dari pesaingnya dan mempertahankan posisi sebagai market leader. Ketiga, perusahaan Speedy disarankan untuk mempertahankan positioning yang ada saat ini karena sudah sesuai dengan persepsi konsumen. Namun, sehubungan dengan peningkatan pangsa pasar yang diiringi peningkatan jumlah pelanggan, disarankan perusahaan harus memperbaiki kemampuan bersaing harga dan keandalan jaringan serta terus memantau posisi dan mengidentifikasi kesenjangan posisi secara berkala untuk menghindari terjadinya kesalahan postioning. 


\section{DAFTAR PUSTAKA}

Hasan, A. (2009). Marketing, edisi baru, Yogyakarta: PT Media Pressindo.

Kasali, R. (2007). Membidik pasar Indonesia: Segmentasi, targeting, positioning, cetakan kedelapan, Jakarta: PT Gramedia Pustaka Utama.

Kertajaya, H. (2004). Hermawan kertajaya on differentiation: Seri 9 elemen marketing, Bandung: MarkPlus\&Co dan PT Mizan Pustaka.

Kotler, P., dan Armstrong, G. (2008). Prinsip-prinsip pemasaran, edisi keduabelas, Jakarta: Erlangga.

Lab Manajemen Ekonomi, Fakultas Ekonomi Jurusan Manajemen. (2008). Modul Praktikum Lab Statistik, Jakarta: Universitas Bina Nusantara.

Prasetijo, T., dan Ihalauw, J.J. (2005). Perilaku konsumen, Yogyakarta: Andi Offset.

Rangkuti, F. (2008). The power of brands, Jakarta: PT Gramedia Pustaka Utama.

Simamora, B. (2005). Analisis multivariat pemasaran, Jakarta: PT Gramedia Pustaka Utama.

Simamora, B. (2008). Panduan riset perilaku konsumen, cetakan ketiga, Jakarta: PT Gramedia Pustaka Utama.

Sugiyono. (2008). Metode penelitian kuantitatif, kualitatif dan R\&D, CV Alfabeta.

Sukandarrumidi. (2006). Metodologi penelitian: Petunjuk praktis untuk peneliti pemula, Yogyakarta: Gajah Mada University Press.

Umar, H. (2005). Riset pemasaran dan perilaku konsumen, Jakarta: PT Gramedia Pustaka Utama. 